\title{
Simulation of the combustion in a dual fuel engine with a divided pilot dose
}

\begin{abstract}
The paper presents a simulation of the combustion process in a dual fuel engine fueled with natural gas and diesel oil with a divided fuel dose. Diesel fuel doses - the pilot and the extra dose were injected at different times and the combustion process was different in terms of dynamics and duration. The task of the additional fuel dose was to maintain combustion, which should lead to improved engine efficiency and better ecological features. Dynamometer tests have confirmed the initial assumptions.

Simulation studies have been conducted based on the original combustion model assuming different combustion of two different doses of diesel oil and natural gas. The parameters of the medium in the combustion chamber and the energy-related effect are a superposition of three separate fuel combustion processes of different combustion dynamics. The validation of the model was based on an SB3.1 engine test (engine operating under variable load and speed).

Simulation studies have shown a significant effect of the initiating dose and the injection angle of the additional dose on the engine combustion parameters. The conclusions from the simulation studies can be used for the adjustment of dual fuel engines fueled with natural gas and diesel oil.
\end{abstract}

Key words: dual fuel engine, divided dose, theoretical model, simulation of combustion

\section{Symulacja procesu spalania w dwupaliwowym silniku z dzieloną dawką oleju napędowego}

W artykule przedstawiono badania symulacyjne procesu spalania $w$ dwupaliwowym silniku zasilanym gazem ziemnym i olejem napędowym z dzielona dawka inicjującą. Dawki oleju napędowego: inicjująca i dodatkowa byly wtryskiwane w różnym czasie, a ich proces spalania byt zróżnicowany odnośnie do dynamiki i czasu. Zadaniem dawki dodatkowej było podtrzymanie procesu spalania mieszaniny gaz-powietrze, co powinno prowadzić do poprawy sprawności silnika i jego cech ekologicznych. Hamowniane badania wstepne potwierdzity te założenia.

Badania symulacyjne przeprowadzono, opierając się na autorskim modelu spalania, zakładającym zróżnicowany przebieg spalania dwu dawek oleju napędowego i gazu. Parametry czynnika w komorze spalania $i$ efekt energetyczny sq superpozycją trzech oddzielnych procesów spalania paliw o zróżnicowanej dynamice. Walidację modelu przeprowadzono na podstawie badań silnika SB3.1 pracującego w zmiennych warunkach obciązenia i prędkości obrotowej.

Badania symulacyjne wykazały istotny wptyw podziału dawki inicjującej oraz kąta opóźnienia wtrysku dawki dodatkowej na parametry spalania silnika. Wnioski z badań symulacyjnych moga być wykorzystane przy doborze regulacji dwupaliwowego silnika zasilanego gazem ziemnym i olejem napędowym.

Słowa kluczowe: silnik dwupaliwowy, podziat dawki, model teoretyczny, symulacja spalania

\section{Introduction}

The coming decade is forecasted to see a dynamic growth of natural gas fueling, particularly in a compressed form (above $20 \mathrm{MPa}$ ). European countries, including the $\mathrm{EU}$ member states, where the $\mathrm{CNG}$ fueling has been given high priority will contribute to this growth. The development of CNG fueling in the EU will be related to a preferential taxation system and support in the building of CNG fueling stations.

In medium sized traction engines used in transport of goods and passengers CNG fueling may be realized in two ways - through spark ignition or dual fueling. The dual fueling system preserves most of the positive features of a traditionally fueled diesel engine. The most important is its high efficiency as compared to spark ignition engines, which contributes to the energy saving policies and remains in line with the applicable legislative policy of many countries worldwide. What is also important is that a dual fuel engine, during a malfunction of the CNG system/or CNG fuel depletion, can be fueled only with diesel oil. This may

\section{Wstęp}

W nadchodzącej dekadzie będzie następował dynamiczny rozwój zasilania silników gazem ziemnym, głównie sprężonym do ciśnień powyżej $20 \mathrm{MPa}$. W rozwoju tym uczestniczyć będą kraje europejskie, w tym kraje Unii Europejskiej, w których zasilaniu gazem CNG nadano wysokie priorytety. Rozwój zasilania CNG w UE związany będzie z preferencyjnym system podatkowym i wspieraniem budowy sieci stacji tankowania.

W silnikach trakcyjnych średniej wielkości, stosowanych w transporcie towarowym i osobowym, zasilanie CNG może odbywać się $\mathrm{w}$ dwóch systemach $-\mathrm{z}$ zapłonem iskrowym lub z systemem dwupaliwowym. System dwupaliwowy pozwala zachować większość pozytywnych cech silnika ZS zasilanego tradycyjnie. Najważniejszą z nich jest wysoka sprawność, w stosunku do silnika z zapłonem iskrowym, przyczyniająca się do poszanowania energii i zgodna $z$ obecną polityką ustawodawczą wielu krajów. Istotne jest również to, że silnik dwupaliwowy przy awarii systemu gazowego lub braku gazu może pracować na samym oleju 
be of paramount importance in the transitory period of $\mathrm{CNG}$ implementation in the market.

The decreasing efficiency at part loads is the basic problem of dual fuel diesel engines. This pushed the authors of this paper to embark on a research on the activation of the combustion of gas-air mixtures under part load conditions. In widely used common rail systems the activation of combustion was attempted through diesel fuel dose division. The authors assumed a diesel fuel dose division into two identical fuel doses injected at different times (constituting $20 \%$ of the total energy supplied in the engine work cycle). The first fuel dose was to initiate the combustion in a time resulting from earlier engine tests research. The second dose injected during active combustion was to maintain the fading combustion of the gas mixture.

The test results have confirmed the assumption on the positive impact of fuel dose division on the combustion process in a dual fuel engine, which, as a consequence, leads to an increase in the engine overall efficiency and an improvement of its ecological properties, particularly a drastic decrease in the $\mathrm{NO}_{\mathrm{x}}$ emission, exhaust opacity. Fuel dose division also reduces the engine noise level and improves its even operation $[5,8,9]$. Positive effects of the tests allow a supposition that this system could be introduced in dual fuel traction engines.

Laboratory engine tests were preceded by a development of a theoretical model of combustion involving fuel dose divisions and a simulation research. This facilitated the selection of the parameters of the fuel doses of diesel oil and natural gas. The developed model and the simulation research have significantly reduced the range of the engine laboratory tests.

\section{The theoretical model of combustion in a dual fuel engine with a diesel fuel dose division}

The basic assumption behind the research is the division of the liquid fuel into two identical doses injected at different times by the common rail system. The controller opens and closes the injector by changing the control times that for the sake of easier control are converted into angular values. The schematic of the division has been presented in Fig. 1.

The division of the dose of diesel oil results in a different combustion of the individual doses.

- The first dose is self-ignited after a delay time characteristic of the liquid fuel and the conditions inside the combustion chamber. Due to the size of the fuel dose (half of the mass of a single dose) in the self-ignition delay time almost the whole fuel evaporates and mixes with air. The combustion rate of this fuel portion is determined by the rate of the chemical reactions and is very high.

- The second fuel dose injected with a delay in the phase of active combustion reacts immediately as the injection continues. The combustion rate is dependent on the evaporation rate and fuel injection. It is a classic diffusive combustion and is relatively slower.

The above- described differences in the combustion of the pilot and the additional fuel doses substantiates the need napędowym. Może to mieć duże znaczenie w przejściowym okresie wprowadzania $\mathrm{CNG}$.

Malejąca sprawność przy częściowych obciążeniach jest podstawowym problemem dwupaliwowych silników o zapłonie samoczynnym. Skłoniło to autorów tego artykułu do podjęcia badań związanych z aktywizacją spalania mieszanin gaz-powietrze w warunkach częściowego obciążenia. Wobec powszechnie stosowanych układów zasobnikowych typu common rail aktywizację spalania mieszanin gazowych starano się realizować przez podział dawki ON. Przyjęto zasadę podziału dawki ON, stanowiącej ok. 20\% całości energii dostarczanej w cyklu pracy silnika, na dwie jednakowe dawki wtryskiwane w różnym czasie. Dawka pierwsza miała za zadanie inicjację spalania w czasie wynikającym z wcześniejszych badań silnika. Dawka druga, wtryskiwana w czasie aktywnego spalania, miała za zadanie podtrzymywać zanikające spalanie mieszaniny gazowej.

Wyniki badań potwierdziły założenia o pozytywnym oddziaływaniu dzielonej dawki na proces spalania w silniku dwupaliwowym, co w efekcie prowadzi do wzrostu sprawności ogólnej silnika i poprawy jego ekologicznych właściwości, a szczególnie radykalnego zmniejszenia $\mathrm{NO}_{\mathrm{x}} \mathrm{i}$ zadymienia spalin, zmniejszenia hałaśliwości oraz poprawy równomierności pracy silnika $[5,8,9]$. Pozytywne efekty badań pozwalają przypuszczać, że system ten może być wprowadzony w trakcyjnych silnikach dwupaliwowych.

Badania hamowniane silnika były poprzedzone opracowaniem modelu teoretycznego spalania w silniku z dzieloną dawką inicjującą oraz wykonaniem badań symulacyjnych. Ułatwiło to dobór parametrów regulacyjnych wtryskiwanych dawek oleju i gazu. Opracowany model i badania symulacyjne skróciły znacznie zakres badań hamownianych silnika.

\section{Teoretyczny model spalania w silniku dwupaliwowym z podziałem dawki oleju napędowego}

Podstawowym założeniem badań jest podział paliwa ciekłego na dwie jednakowe dawki wtryskiwane w różnym czasie przez sterownik układu CR. Sterownik otwiera i zamyka wtryskiwacz przez zmiany czasów sterowania, które dla wygody obsługi przeliczone są na wartości kątowe. Schemat podziału przedstawiono na rys. 1 .

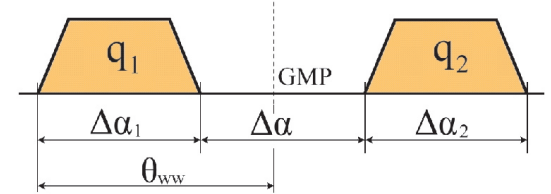

Fig. 1. Schematics of the division of the diesel oil dose Rys. 1. Schemat podzialu dawki oleju napędowego

Podział dawki oleju napędowego powoduje zróżnicowanie spalania poszczególnych dawek.

- Dawka pierwsza ulega samozapłonowi po okresie opóźnienia charakterystycznym dla paliwa ciekłego i warunków panujących w komorze spalania. Z uwagi na wielkość 
for model research on the influence of the fuel dose size, delay angle $\Delta \alpha$ and injection angle $\theta_{\text {ww }}$ on the course of the heat and pressure release in the period of active combustion. The simulation research aimed at reducing the range of the laboratory tests needed to adapt the engine to dual fueling.

In the development of the theoretical model the authors used extensive experience of the Chair of Combustion Engines and Vehicles at University of Bielsko-Biała in modeling of engine processes described in works [6-8].

\subsection{Mathematical formulas used in the model}

The changes in the parameters of the medium were calculated from the energy balance of the first law of dynamics and the equation of state:

$$
\begin{gathered}
\frac{\mathrm{dQ}_{\mathrm{d}}}{\mathrm{d} \tau}=\frac{\mathrm{dU}}{\mathrm{d} \tau}+\mathrm{p} \cdot \frac{\mathrm{dV}}{\mathrm{d} \tau}+\mathrm{h}_{\mathrm{on}} \cdot \frac{\mathrm{dm}_{\mathrm{on}}}{\mathrm{d} \tau}+\frac{\mathrm{dQ}_{\mathrm{s}}}{\mathrm{d} \tau} \\
\mathrm{p} \cdot \mathrm{V}=\mathrm{n} \cdot \mathrm{R} \cdot \mathrm{T}
\end{gathered}
$$

where: $\mathrm{Q}_{\mathrm{d}}$ - heat release in the combustion chamber, $\mathrm{m}_{\text {on }}$ mass of the diesel oil injected into the combustion chamber, $\mathrm{h}_{\text {on }}$ - diesel oil enthalpy, $\mathrm{Q}_{\mathrm{s}}$ - heat losses through the walls, $\mathrm{n}$ - current molar number of the medium in the combustion chamber.

The heat release rate was calculated from the formula:

$$
\frac{\mathrm{dQ}_{\mathrm{d}}}{\mathrm{d} \tau}=\frac{\mathrm{dQ}_{\mathrm{on} 1}}{\mathrm{~d} \tau}+\frac{\mathrm{dQ}_{\mathrm{on} 2}}{\mathrm{~d} \tau}+\frac{\mathrm{dQ}_{\mathrm{g}}}{\mathrm{d} \tau}
$$

Instantaneous increments of released heat:

$$
\begin{aligned}
& \frac{\mathrm{dQ}_{\mathrm{on} 1}}{\mathrm{~d} \tau}=\zeta_{\mathrm{on}} \cdot \mathrm{m}_{\mathrm{on} 1} \cdot \mathrm{H}_{\mathrm{on}} \cdot \frac{\mathrm{dX}_{\text {onl }}}{\mathrm{d} \tau} \\
& \frac{\mathrm{dQ}_{\text {on } 2}}{\mathrm{~d} \tau}=\zeta_{\mathrm{on}} \cdot \mathrm{m}_{\text {on } 2} \cdot \mathrm{H}_{\mathrm{on}} \cdot \frac{\mathrm{dX}_{\text {on } 2}}{\mathrm{~d} \tau} \\
& \frac{\mathrm{dQ}_{\mathrm{g}}}{\mathrm{d} \tau}=\zeta_{\text {on }} \cdot \mathrm{m}_{\mathrm{g}} \cdot \mathrm{H}_{\mathrm{g}} \cdot \frac{\mathrm{dX} \mathrm{g}}{\mathrm{d} \tau}
\end{aligned}
$$

where: $\mathrm{m}_{\mathrm{on} 1}, \mathrm{~m}_{\mathrm{on} 2}, \mathrm{~m}_{\mathrm{g}}-$ mass of the first and second diesel fuel dose and natural gas per one cycle of work [ $\mathrm{kg} / \mathrm{cycle}]$, $\xi_{\mathrm{on}}, \xi_{\mathrm{g}}$ - coefficient of unburned diesel and $\mathrm{CNG}[-], \mathrm{H}_{\text {on' }}$, $\mathrm{H}_{\mathrm{g}}$ - combustion heat for diesel oil and $\mathrm{CNG}[\mathrm{MJ} / \mathrm{kg}], \mathrm{X}_{\text {on } 1}$, $\mathrm{X}_{\mathrm{on} 2}, \mathrm{X}_{\mathrm{g}}$ - Wiebe combustion functions for: pilot fuel dose, additional fuel dose, CNG [-].

Wiebe functions were determined from the relation:

$$
\begin{aligned}
& \mathrm{X}_{\mathrm{on} 1}=1-\exp \left[-6,908\left(\frac{\alpha-\alpha_{\mathrm{ps} 1}}{\alpha_{\mathrm{ks} 1}-\alpha_{\mathrm{ps} 1}}\right)^{\mathrm{m}_{\mathrm{on} 1}+1}\right] \\
& \mathrm{X}_{\mathrm{on} 2}=1-\exp \left[-6,908\left(\frac{\alpha-\alpha_{\mathrm{ps} 2}}{\alpha_{\mathrm{ks} 2}-\alpha_{\mathrm{ps} 2}}\right)^{\mathrm{m}_{\mathrm{on} 2}+1}\right] \\
& \mathrm{X}_{\mathrm{g}}=1-\exp \left[-6,908\left(\frac{\alpha-\alpha_{\mathrm{ps} 1}}{\alpha_{\mathrm{ksg}}-\alpha_{\mathrm{ps} 1}}\right)^{\mathrm{m}_{\mathrm{wg}}+1}\right]
\end{aligned}
$$

dawki (połowa masy dawki pojedynczej) w okresie opóźnienia samozapłonu prawie całe paliwo odparowuje i miesza się z powietrzem. Spalanie tej porcji paliwa odbywa się z prędkością determinowaną przez szybkość reakcji chemicznych i jest bardzo szybkie.

- Dawka druga wtryskiwana z opóźnieniem, w fazie aktywnego spalania, wchodzi w reakcję natychmiast w miarę postępu wtrysku. Szybkość spalania uzależniona jest od szybkości parowania i wtrysku paliwa. Spalanie odbywa się wg klasycznego spalania dyfuzyjnego i jest relatywnie wolniejsze.

Opisane wyżej różnice spalania dawki inicjującej i dodatkowej uzasadniają konieczność badań modelowych, które powinny dotyczyć wpływu wielkości dawki, kąta opóźnienia $\Delta \alpha$ oraz kąta wyprzedzenia wtrysku $\theta_{\text {ww }}$ na przebieg wydzielania ciepła i ciśnienia w okresie aktywnego spalania. Badania symulacyjne miały za zadanie zmniejszyć zakres badań hamownianych koniecznych do adaptacji silnika do zasilania dwupaliwowego.

Przy opracowywaniu modelu teoretycznego wykorzystano wieloletnie doświadczenia Katedry Silników Spalinowych i Pojazdów ATH w modelowaniu procesów silnikowych, opisane w pracach [6-8].

\subsection{Wzory matematyczne stosowane w modelu}

Zmiany parametrów czynnika obliczano z równania bilansu energii I zasady termodynamiki i równania stanu (1) i (2), gdzie: $\mathrm{Q}_{\mathrm{d}}$ - ciepło wydzielone w komorze spalania, $\mathrm{m}_{\text {on }}$ - masa oleju napędowego wtryskiwana do komory spalania, $\mathrm{h}_{\text {on }}$ - entalpia oleju napędowego, $\mathrm{Q}_{\mathrm{s}}$ - straty cieplne do ścianek, $\mathrm{n}$ - aktualna liczba moli czynnika w komorze spalania.

Szybkość wydzielania ciepła obliczano z wzoru (3).

Chwilowe przyrosty wydzielonego ciepła - wzory (4), (5) i (6), gdzie: $m_{\text {on1 }}, m_{\text {on2 }}, m_{g}$ - masy pierwszej i drugiej dawki oleju napędowego oraz gazu przypadające na jeden cykl pracy [kg/cykl], $\xi_{\text {on }}, \xi_{\mathrm{g}}$ - współczynniki niedopału dla $\mathrm{ON}$ i CNG [-], $\mathrm{H}_{\text {on }}, \mathrm{H}_{\mathrm{g}}$ - ciepło spalania ON i CNG [MJ/ $\mathrm{kg}], \mathrm{X}_{\text {on1 }}, \mathrm{X}_{\text {on2 }}, \mathrm{X}_{\mathrm{g}}$ - funkcje spalania Wibego odpowiednio: dawki inicjującej, dawki dodatkowej, gazu [-].

Funkcje Wibego określono z zależności (7), (8) i (9), gdzie: $\alpha$ - kąt obrotu wału korbowego [ $\left.{ }^{\circ} \mathrm{OWK}\right], \alpha_{\mathrm{ps} 1}-$ kąt początku spalania $\left[{ }^{\circ} \mathrm{OWK}\right], \alpha_{\mathrm{ps} 2}$ - kąt początku spalania dawki dodatkowej ON [ $\left.{ }^{\circ} \mathrm{OWK}\right], \alpha_{\mathrm{ks} 1}, \alpha_{\mathrm{ks} 2}, \alpha_{\mathrm{ksg}}-$ kąt końca spalania pierwszej dawki, dodatkowej dawki ON i gazu $\left[{ }^{\circ} \mathrm{OWK}\right], \mathrm{m}_{\text {on1 }}, \mathrm{m}_{\text {on2 } 2}, \mathrm{~m}_{\mathrm{wg}}-$ wykładniki funkcji Wibego dla dawek ON i gazu [-].

Przy obliczaniu funkcji spalania Wibego przyjęto założenie, że spalanie dawki inicjującej i gazu rozpoczyna się równocześnie dla kąta $\alpha_{\mathrm{ps} 1}$, natomiast zakończenie w różnych czasach $-\alpha_{\mathrm{ks} 1}$ i $\alpha_{\mathrm{ksg}}$. Początek i koniec spalania dawki dodatkowej jest przesunięty w czasie i odmienny od dawki inicjującej $-\alpha_{\mathrm{ps} 2}$ i $\alpha_{\mathrm{ks} 2}$.

Dynamika spalania poszczególnych porcji paliw jest zróżnicowana przez różne wykładniki funkcji Wibego odpowiednio: $\mathrm{m}_{\mathrm{on} 1}, \mathrm{~m}_{\mathrm{on} 2} \mathrm{i} \mathrm{m}_{\mathrm{g}}$.

\subsection{Walidacja modelu teoretycznego}

Walidację modelu przeprowadzono na podstawie wyników badań przez porównanie symulowanego przebiegu ciśnienia czynnika w cylindrze z ciśnieniem rejestrowanym 
where: $\alpha$ - crankshaft angle $\left[{ }^{\circ} \mathrm{CA}\right], \alpha_{\mathrm{ps} 1}$ - angle of start of combustion $\left[{ }^{\circ} \mathrm{CA}\right], \alpha_{\mathrm{ps} 2}$ - angle of start of combustion of the additional diesel fuel dose $\left[{ }^{\circ} \mathrm{CA}\right], \alpha_{\mathrm{ks} 1}, \alpha_{\mathrm{ks} 2}, \alpha_{\mathrm{ksg}}-$ angle of end of combustion of the first, the additional dose of diesel fuel and $\mathrm{CNG}\left[{ }^{\circ} \mathrm{CA}\right], \mathrm{m}_{\mathrm{on} 1}, \mathrm{~m}_{\mathrm{on} 2}, \mathrm{~m}_{\mathrm{wg}}-$ Wiebe function exponents for diesel oil an CNG [-].

When calculating the Wiebe combustion function an assumption was made that the combustion of the pilot dose and CNG start at the same time for angle $\alpha_{\mathrm{psl}}$, but the end takes place at different times $-\alpha_{\mathrm{ks1}}$ and $\alpha_{\mathrm{ksg}}$. The start and the end of the combustion of the additional fuel dose is shifted in time and is different from the pilot fuel dose $-\alpha_{\mathrm{ps} 2}$ and $\alpha_{\mathrm{ks} 2}$.

The combustion dynamics of the individual portions of the fuels is varied due to different exponents of the Wiebe functions: $\mathrm{m}_{\mathrm{on} 1}, \mathrm{~m}_{\mathrm{on} 2}$ and $\mathrm{m}_{\mathrm{g}}$.

\subsection{Validation of the theoretical model}

The validation of the model was performed based on the test results by comparing the simulated course of pressure of the medium inside the cylinder with the pressure recorded when the engine operated on the engine test bed. The comparison was made for the same engine loads and speeds

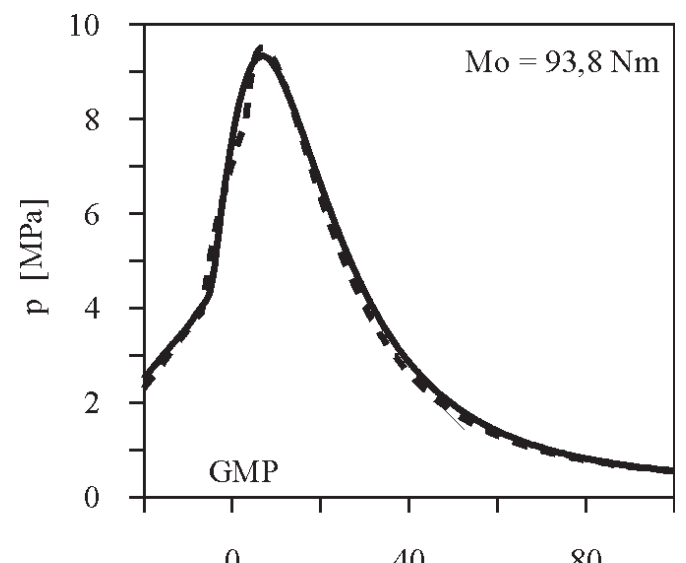

Kąt obrotu wału korbowego $\alpha \quad\left[{ }^{\circ} \mathrm{OWK}\right]$

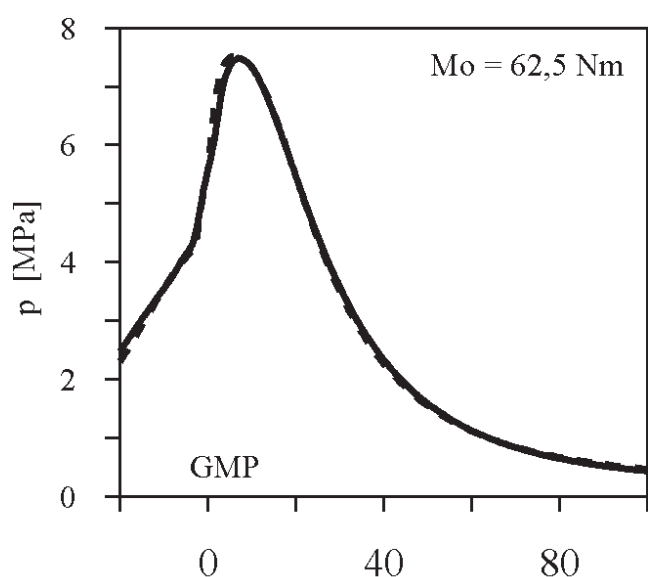

Kąt obrotu wału korbowego $\alpha \quad\left[{ }^{\circ} \mathrm{OWK}\right]$ w czasie pracy silnika na hamowni. Porównania dokonano dla tych samych obciążeń silnika i prędkości obrotowych, wprowadzając do modelu wartości zużycia ON, gazu i powietrza oraz parametry czynnika i warunki podziału dawki ON takie same jak rejestrowane podczas badań. Parametrami zmiennymi były zmienne niezależne charakteryzujące proces spalania paliw: $\alpha_{\mathrm{ps} 1}, \alpha_{\mathrm{ps} 2}, \alpha_{\mathrm{psg}}, \alpha_{\mathrm{sp1}}, \alpha_{\mathrm{sp} 2}, \alpha_{\mathrm{spg}}, \mathrm{m}_{\mathrm{on} 1}, \mathrm{~m}_{\mathrm{on} 2}, \mathrm{~m}_{\mathrm{wg}}$. Wymienione parametry zmieniano, tak aby symulowany przebieg ciśnienia był zbliżony do ciśnienia mierzonego $\mathrm{z}$ zadowalającą dokładnością. Przykładowe wyniki porównania przedstawiono na rys. 2 . W tabeli zamieszczonej na rys. 2 podano wartości zmiennych niezależnych użyte w symulacji ciśnień. Porównanie ciśnień wykazało wystarczającą zgodność ciśnień we wszystkich analizowanych punktach.

W celu analizy dokładności odwzorowania ciśnień przedstawiono błędy bezwzględne i względne między ciśnieniami mierzonymi i symulowanymi obliczone z wzorów (10) i (11), gdzie: $\mathrm{p}_{\mathrm{m}}$ - ciśnienie mierzone w czasie badań, $\mathrm{p}_{\mathrm{s}}$ - ciśnienie symulowane.

Przykładowe przebiegi błędów przedstawiono na rys. 3. Przy maksymalnych obciążeniach silnika błąd odwzorowa-

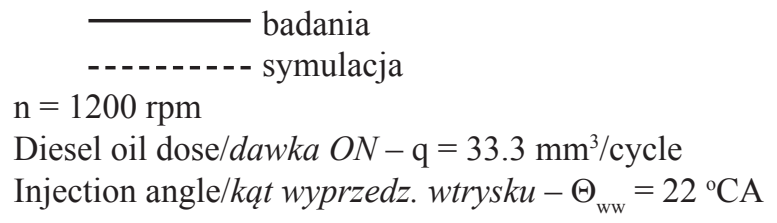

\begin{tabular}{|l|c|c|c|}
\hline Parameter & \multicolumn{3}{|c|}{ Torque/moment obrotowy } \\
\hline & $93.8 \mathrm{Nm}$ & $62.5 \mathrm{Nm}$ & $31.3 \mathrm{Nm}$ \\
\hline $\mathrm{m}_{\text {on1 }}$ & 0.3 & 0.34 & 0.44 \\
\hline $\mathrm{m}_{\text {on2 }}$ & 0.2 & 0.26 & 0.36 \\
\hline $\mathrm{m}_{\mathrm{wg}}$ & 1,2 & 1.4 & 2.4 \\
\hline$\alpha_{\mathrm{sp1}}$ & 10 & 10 & 10 \\
\hline$\alpha_{\mathrm{sp} 2}$ & 7 & 9 & 16 \\
\hline$\alpha_{\mathrm{spg}}$ & 27 & 32 & 44 \\
\hline
\end{tabular}

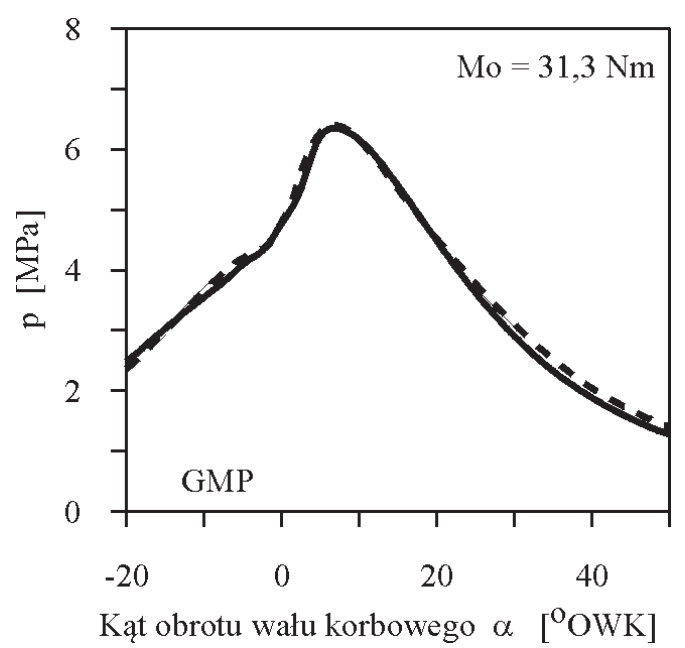

Fig. 2. Comparison of the pressure measured during the engine tests and the simulated one for different engine loads: engine speed $1200 \mathrm{rpm}$, divided dose $50 / 50 \%$, delay angle $\Delta \alpha=10^{\circ} \mathrm{CA}$

Rys. 2. Porównanie ciśnienia mierzonego podczas badań silnika i symulowanego dla różnych obciążeń silnika: prędkość obrotowa 1200 obr/min, dawka dzielona 50/50\%, kąt zwłoki $\Delta \alpha=10^{\circ} \mathrm{OWK}$ 
introducing in the model the values of the diesel oil, $\mathrm{CNG}$ and air consumption as well as the parameters of the medium and conditions of the diesel fuel dose division (the same as the ones recorded during the tests). The variable parameters were independent variables characterizing the combustion of the fuels: $\alpha_{\mathrm{ps} 1}, \alpha_{\mathrm{ps} 2}, \alpha_{\mathrm{psg}}, \alpha_{\mathrm{sp} 1}, \alpha_{\mathrm{sp} 2}, \alpha_{\mathrm{spg}}, \mathrm{m}_{\mathrm{on1}}, \mathrm{m}_{\mathrm{on2} 2}, \mathrm{~m}_{\mathrm{wg}}$. The said parameters were modified so that the simulated course of pressure was sufficiently close to the measured one. Example results of the comparison have been shown in Fig. 2. Table in Fig. 2 shows the values of the independent variables used for the simulation of pressures. The comparison of the pressures has shown a sufficient conformity of the pressures in all analyzed points.

In order to analyze the accuracy of the reflection of the pressure absolute and relative errors have been presented related to the measured and simulated pressures calculated from the formulas:

$$
\begin{gathered}
\Delta p=p_{m}-p_{s} \\
\delta p=\frac{p_{m}-p_{s}}{p_{m}} \cdot 100 \%
\end{gathered}
$$

where: $p_{m}-$ pressure measured during the tests, $p_{s}-$ simulated pressure.

Example courses of errors have been presented in Fig. 3. At maximum engine loads the error of the reflection of the pressure is not big and the absolute value of the pressure differences does not exceed 0.4 $\mathrm{MPa}$. The greatest pressure differences occur in the range of maximum pressure increment rates and during active combustion, which corresponds to high values of the pressure of the medium inside the cylinder. In the range of compression and the final phase of the decompression the pressure differences decrease. Similar conclusion was reached from the analysis of the differences $\Delta \mathrm{p}$ for the minimum engine load. In the subsequent phases of the decompression the differences of the simulated and measured pressure were miniscule $(<0.1 \mathrm{MPa})$, which confirms the good quality of pressure reflection.

From the analysis of the courses of $\delta p$ it results that in the range of active combustion relative errors fall within the range of $-8 \div+8 \%$. In the range of angles corresponding to the subsequent phase of decompression the absolute values of $\delta p$ increase despite small values of $\Delta \mathrm{p}$, which results from small values of pressures $\mathrm{p}_{\mathrm{m}}$

The analysis of the courses of the absolute and relative deviations indicates that the developed program may be used to select the parameters of the injection control of diesel oil and $\mathrm{CNG}$ and predict the pressure course in dual fuel engines with diesel fuel dose division. Modeling of the strategy of fuel dose division may provide information on the engine parameters and the forecasted values of the maximum pressure and pressure increment rate, the crank-piston loads and engine noise. nia ciśnienia nie jest duży, a wartość bezwzględna różnic ciśnień nie przekracza $0,4 \mathrm{MPa}$. Największe różnice ciśnień występują w zakresie maksymalnych szybkości narastania ciśnienia oraz w zakresie aktywnego spalania, co odpowiada dużym wartościom ciśnienia czynnika w cylindrze. W zakresie sprężania i końcowej fazy rozprężania różnice ciśnień maleją. Podobne wnioski otrzymano z analizy różnic $\Delta \mathrm{p}$ dla minimalnego obciążenia silnika. W późniejszych fazach rozprężania różnice ciśnień symulowanych i mierzonych były niewielkie $(<0,1 \mathrm{MPa})$, co potwierdza dobrą jakość odwzorowania ciśnień.

Z analizy przebiegów $\delta$ p wynika, że w zakresie aktywnego spalania błędy względne odwzorowania ciśnień mieszczą się w przedziale $-8 \div+8 \%$. W zakresie kątów odpowiadających późniejszej fazie rozprężania bezwzględne wartości $\delta p$ wzrastają, mimo małych wartości $\Delta \mathrm{p}$, co wynika z małych wartości ciśnień $\mathrm{p}_{\mathrm{m}}$.

Analiza przebiegów odchyłek bezwzględnych i względnych ciśnień wskazuje, że opracowany program może być wykorzystany do doboru parametrów sterowania wtryskiem oleju napędowego i gazu oraz przewidywania przebiegu ciśnienia w dwupaliwowych silnikach z podziałem dawki ON. Modelowanie strategii podziału dawki może dać informację o parametrach silnika i przewidywanie wartości maksymalnego ciśnienia i szybkości przyrostu ciśnienia o obciążeniu mechanizmu korbowego oraz hałaśliwości silnika.

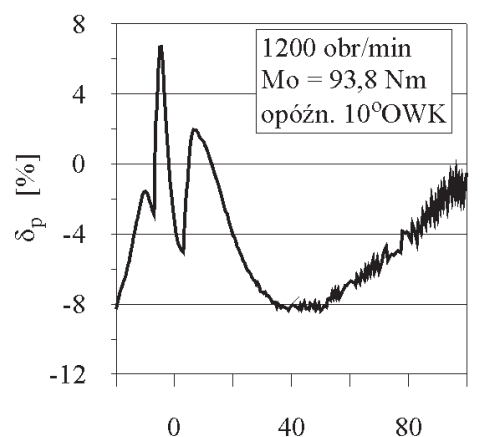

Kąt obrotu wału korbowego $\alpha\left[{ }^{\circ} \mathrm{OWK}\right]$

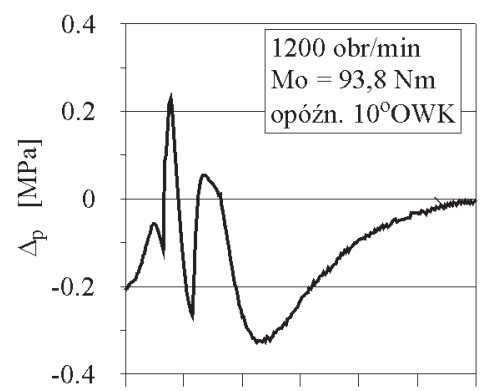

$\begin{array}{lll}0 & 40 \quad 80\end{array}$

Kąt obrotu wału korbowego $\alpha\left[{ }^{\circ} \mathrm{OWK}\right]$
Fig. 3. Comparison of relative and absolute pressure differences measured and simulated at maximum engine loads

Rys. 3. Porównanie bezwzględnych i względnych różnic ciśnienia mierzonego i symulowanego przy maksymalnych obciażeniach silnika

\section{Analiza wyników badań symulacyjnych}

Badania symulacyjne przeprowadzono przy założeniu podziału dawki na dwie równe części w stosunku 50\%/50\%. Wykorzystano przy tym wielkości dawek oleju napędowego i gazu takie jak występujące w badaniach hamownianych silnika SB3.1. Przy zmianach parametrów zasilania i różnych wariantach parametrów określających dynamikę spalania stosowano zasadę stałej ilości energii dostarczanej sumarycznie wraz z paliwem ciekłym i gazowym. Przy uwzględnieniu kąta wyprzedzenia wtrysku dawki inicjującej $\theta_{\text {ww }}$, kąta opóźnienia samozapłonu $\theta_{\mathrm{oz}}$ oraz opóźnienia wtrysku dawki dodatkowej $\Delta \alpha$, czasowe zależności spalania poszczególnych dawek mogą być charakteryzowane jak na 


\section{Analysis of the results of the simulation research}

The simulation research was performed assuming the fuel dose division into two identical parts $(50 \% / 50 \%)$. The size of the fuel doses of diesel oil and CNG was the same as the one used on the engine test bed (SB3.1. engine). When changing the fueling parameters and applying different variants of the parameters determining the dynamics of the combustion a principle of constant amount of total collective energy was applied (diesel fuel and CNG). When considering the injection angle of the pilot dose $\theta_{w w}$, self-ignition delay angle

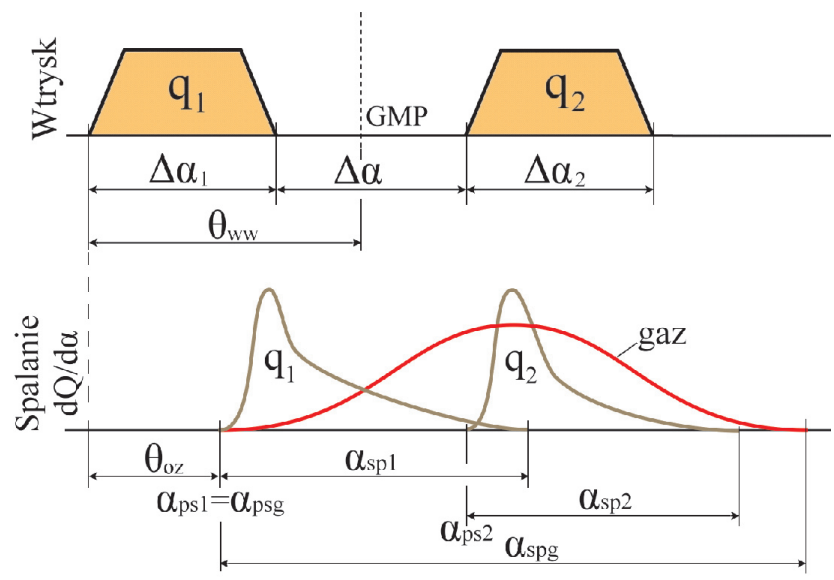

Fig. 4. Schematics of the injection of diesel oil and combustion of the fuels in a dual fuel engine with fuel dose division

Rys. 4. Schemat wtrysku oleju napędowego i spalania paliw w silniku dwupaliwowym z podziałem dawki inicjujacej

$\theta_{\text {oz }}$ and injection delay angle of the additional dose $\Delta \alpha$ the time relations of the combustion of individual doses may be characterized as in Fig. 4. An assumption was made that the combustion of diesel fuel from the second fuel dose initiated with the injection of the fuel, which results from the ongoing process of active combustion and high temperatures of the reactants (good fuel atomization and negligible angle of self-ignition delay). In the below presented investigations the authors also assumed that the combustion of CNG initiates with the start of combustion of the first diesel fuel dose. In practice it may be delayed by the angle of induction resulting from the flame development in the gas mixture depending on its composition (at high excess air coefficient this angle may be noticeable) [6]. The values of $\Delta \alpha_{1}, \Delta \alpha, \Delta \alpha_{2}$ were calculated based on the injector opening times determined in the engine laboratory tests and based on the analyzed engine speed and the values of $\Delta \alpha_{1}=\Delta \alpha_{2}$ are dependent on the size of the pilot fuel dose q.

Figure 5 presents the influence of the injection delay angle of the additional dose on the selected combustion parameters. The modification of the injection delay angle of the additional fuel dose influences the course of the pressure during the combustion, particularly in the range between the start of the combustion and the point of maximum pressure. Small delay angles 5 and $10^{\circ} \mathrm{CA}$ show minuscule changes in the pressure course, which results from a partial overlapping rys. 4. Przyjęto przy tym założenie, że spalanie ON z drugiej dawki rozpoczyna się wraz z wtryskiem paliwa, co wynika z trwającego procesu aktywnego spalania i wysokich temperatur reagentów (dobre rozpylenie paliwa i pomijalnie mały kąt zwłoki samozapłonu). W zaprezentowanych niżej badaniach przyjmowano również, że spalanie gazu rozpoczyna się równocześnie z początkiem spalania pierwszej dawki ON. W rzeczywistości może być ono opóźnione o kąt indukcji, wynikający z rozwoju płomienia w mieszaninie gazowej, zależny od jej składu (przy dużym współczynniku nadmiaru powietrza kąt ten może być zauważalny) [6]. Wartości kątów $\Delta \alpha_{1}, \Delta \alpha, \Delta \alpha_{2}$ obliczano na podstawie czasów otwarcia wtryskiwaczy określonych w badaniach hamownianych silnika oraz na podstawie analizowanej prędkości obrotowej, przy czym wartości $\Delta \alpha_{1}=\Delta \alpha_{2}$ zależne są od wielkości dawki inicjującej q.

Na rysunku 5 przedstawiono wpływ kąta opóźnienia wtrysku dawki dodatkowej na wybrane parametry spalania. Zmiana kąta opóźnienia wtrysku dawki dodatkowej wpływa na przebieg ciśnienia czynnika podczas spalania, szczególnie $\mathrm{w}$ przedziale między początkiem spalania a punktem maksymalnego ciśnienia. Małe kąty opóźnienia 5 i 10 ${ }^{\circ} \mathrm{OWK}$ wykazują niewielkie zmiany w przebiegu ciśnienia, co wynika z częściowego nakładania się procesu spalania obydwu dawek. Zwiększenie kąta opóźnienia do $15^{\circ} \mathrm{OWK}$ powoduje pojawienie się na linii ciśnienia punktu przegięcia, odpowiadającego dużej dynamice spalania dawki dodatkowej i opóźnienie względem GMP punktu maksymalnego ciśnienia. Jeszcze wyraźniejsze zmiany ciśnienia występują po zwiększeniu kąta opóźnienia do $20^{\circ} \mathrm{OWK}$.

Zmiany symulowanej dynamiki spalania oleju napędowego widoczne są wyraźnie na przebiegach szybkości wydzielania ciepła $(\mathrm{dQ} / \mathrm{d} \alpha)_{\text {on }}$ (rys. 5). Przy małym kącie opóźnienia $5{ }^{\circ} \mathrm{OWK}$ procesy spalania obydwu dawek przebiegają prawie w tym samym czasie, co wynika z kąta opóźnienia samozapłonu dla pierwszej dawki. Dopiero zwiększenie kąta opóźnienia powyżej $10{ }^{\circ} \mathrm{OWK}$ pokazuje na rozdzielne w czasie spalanie obydwu dawek i występujące dwa lokalne maksima szybkości wydzielania ciepła dla dawki pierwszej i drugiej.

Zmiany dynamiki spalania oleju napędowego wynikające ze zmiennego kąta opóźnienia wtrysku dawki dodatkowej wpływają również na sumaryczną szybkość wydzielania cie$\mathrm{pła}(\mathrm{dQ} / \mathrm{d} \alpha)_{\text {on }+\mathrm{g}}$. Dla kątów $\Delta \alpha$ równych $10^{\circ} \mathrm{OWK}$ i większych na krzywych $(\mathrm{dQ} / \mathrm{d} \alpha)_{{ }_{\text {on }} \text { g }}$ pojawiają się dwa maksima lokalne wynikające z maksymalnej dynamiki spalania dawki inicjującej i dodatkowej. Równocześnie maksymalna szybkość wydzielania ciepła $(\mathrm{dQ} / \mathrm{d} \alpha)_{\max }$ maleje, a punkt jej występowania jest coraz bardziej opóźniony w stosunku do GMP.

Kąty opóźnienia w przedziale $5 \div 15^{\circ} \mathrm{OWK}$ nie wpływają na sprawność indykowaną silnika, co wynika prawdopodobnie z małego udziału ON w całkowitej dawce energii dostarczanej do silnika (ok. 20\%). Dopiero kąt opóźnienia 20 ${ }^{\circ} \mathrm{OWK}$ powoduje zmniejszenie sprawności indykowanej $\eta_{\mathrm{i}} \mathrm{O}$ około 3\% (rys. 5). Opóźnienie wtrysku dawki dodatkowej o kąt większy niż $10^{\circ} \mathrm{OWK}$ powoduje zmniejszenie wartości średniego ciśnienia indykowanego $\mathrm{p}_{\mathrm{i}}$. 
of the combustion of both fuel doses. An increase of the injection delay angle to $15{ }^{\circ} \mathrm{CA}$ results in the appearance of an inflection corresponding to high dynamics of the combustion of the additional fuel dose and a delay against TDC of the point of maximum pressure. Even more conspicuous pressure changes occur upon an increase of the delay angle to 20 ${ }^{\circ} \mathrm{CA}$.

The changes of the simulated dynamics of the combustion of diesel oil are clearly seen in the courses of the heat release $(\mathrm{dQ} / \mathrm{d} \alpha)_{\text {on }}$ (Fig. 5). At a small delay angle $5{ }^{\circ} \mathrm{CA}$ the combustion process of both fuel doses occurs almost in the same time, which results from the self-ignition delay angle from the first fuel dose. Only an increase in the delay angle above $10^{\circ}$ CA indicates a separatein-time combustion of both fuel doses and an occurrence of two local maximums of heat release rates for the pilot and the additional fuel doses.

The changes in the dynamics of combustion of diesel oil resulting from the variable angle of injection delay of the additional fuel dose also influence the collective heat release rate $(\mathrm{dQ} / \mathrm{d} \alpha)_{\mathrm{on}+\mathrm{g}}$. For the angles $\Delta \alpha$ of $10^{\circ}$ and more CA on the curves $(\mathrm{dQ} / \mathrm{d} \alpha)_{\text {on }+\mathrm{g}}$ appear two local maximums resulting from the maximum combustion dynamics of the pilot and the additional doses. At the same time the maximum heat release rate $(\mathrm{dQ} / \mathrm{d} \alpha)_{\max }$ decreases and the point of its occurrence is increasingly delayed against TDC.

The delay angles in the range $5 \div 15^{\circ} \mathrm{CA}$ do not influence the indicated efficiency of the engine, which is probably due to the low share of diesel oil in the total energy dose supplied to the engine (approximately 20\%). Only the delay angle of $20{ }^{\circ} \mathrm{CA}$ leads to a decrease in the indicated $\eta_{\mathrm{i}}$ by approximately 3\% (Fig. 5). The injection delay of the additional dose by an angle greater than $10{ }^{\circ} \mathrm{CA}$ results in a reduction of the value of mean indicated pressure $\mathrm{p}_{\mathrm{i}}$.
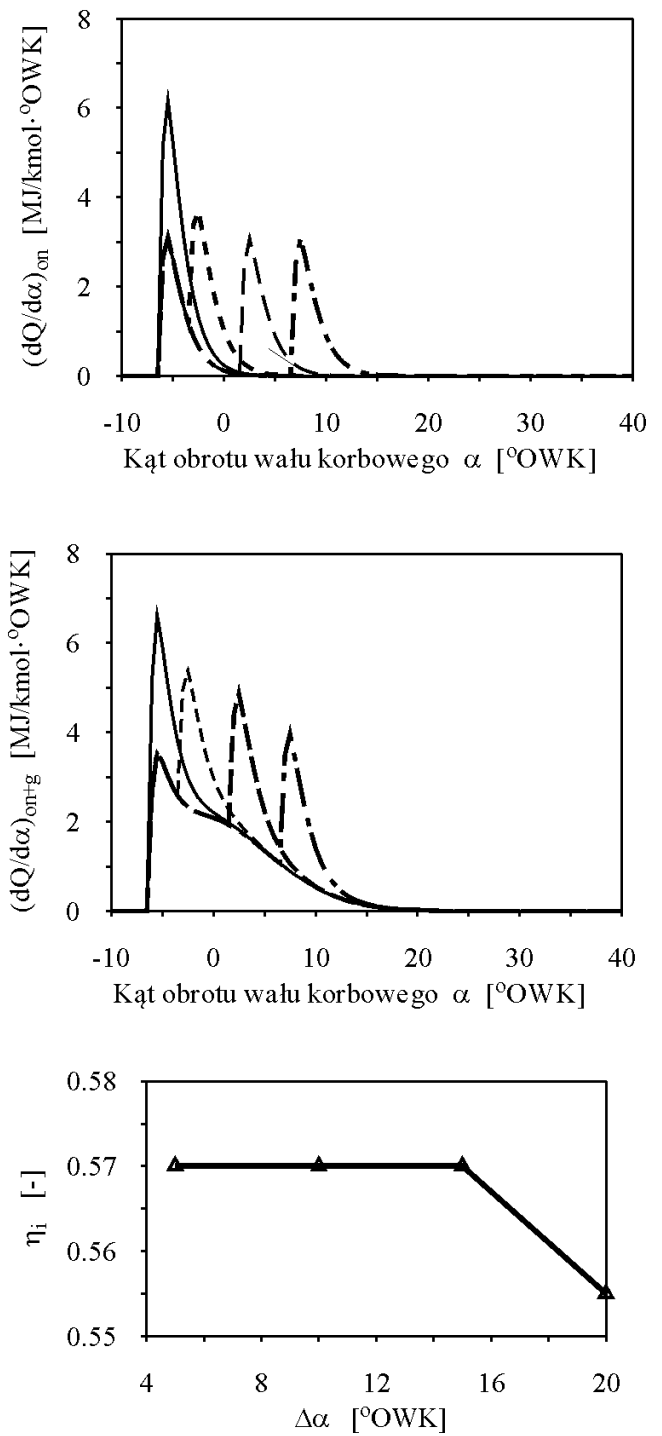

Fig. 5. The influence of the injection delay angle of the additional fuel dose on selected engine parameters: engine speed $1400 \mathrm{rpm}$; maximum load

rysku dawki dodatkowej na wybrane parametry silnika: prędkość obrotowa $1400 \mathrm{obr} / \mathrm{min}$; obciążenie maksymalne

Wpływ zmiany kąta spalania dawek ON na wybrane parametry spalania przedstawiono na rys. 6 . Kąty spalania $\alpha_{\mathrm{sp1}}, \alpha_{\mathrm{sp} 2}$, zależą od jakości rozpylenia paliwa ciekłego, kąta wyprzedzenia wtrysku, zwłoki samozapłonu, wielkości dawki i parametrów termicznych czynnika oraz geometrii komory spalania. Tak duża liczba czynników wpływających na wymienione kąty powoduje, że trudno jest bez badań doświadczalnych przyjąć właściwe kąty spalania odpowiadające określonym warunkom pracy silnika. $Z$ tego powodu badania symulacyjne mogą wskazywać jedynie kierunki zmian parametrów silnika, jednak bez określenia ich zależności ilościowych.

W badaniach (rys. 6) przyjęto zmiany kąta spalania w zakresie $10 \div 40{ }^{\circ} \mathrm{OWK}$ prawdopodobnie szerszym od rzeczywiście występujących w silnikach dwupaliwowych średniej wielkości pracujących na małych dawkach inicjujących. Symulacje przeprowadzono dla dwóch wykładni- 
The influence of the change of the combustion angle of the diesel fuel doses on selected parameters of combustion has been presented in Fig. 6. Combustion angles $\alpha_{\mathrm{sp} 1}, \alpha_{\mathrm{sp} 2}$ depend on the quality of liquid fuel atomization, ignition angle, self-ignition delay, size of the fuel dose, thermal parameters of the medium as well as geometry of the combustion chamber. Such a great number of factors influencing the said angles makes it difficult to adopt the right combustion angles corresponding to the individual engine operating conditions without experimental research. For this reason the simulation research can only indicate trends in the engine parameters, yet without determining of the quantitative relations.

In the research (Fig. 6) changes in the angle in the range of $10 \div 40^{\circ} \mathrm{CA}$ were adopted (probably wider than the actually occurring in medium sized dual fuel engines operating on small pilot fuel doses). The simulations were performed for two Wiebe function exponents equaling 0.3 and 1.0 ków funkcji Wibego równych 0,3 i 1,0, jednakowych dla obydwu dawek oraz dla średniej dynamiki spalania gazu $\mathrm{m}_{\mathrm{wg}}=1,8$. Kąt spalania gazu był stały, niezależnie od zmian kąta spalania ON. Należy tu podkreślić, że w rzeczywistych warunkach zmiany kąta spalania paliwa ciekłego wpływają na zmiany kąta spalania gazu, ale zasadnicze znaczenie ma skład mieszaniny gaz-powietrze, szczególnie w ubogich zakresach składów.

W miarę zwiększania kąta spalania dawek ON ciśnienia maksymalne maleją, a punkt ich występowania przesuwa się w prawo w kierunku większych kątów po GMP. Wynika to ze stopniowego zmniejszania szybkości wydzielania ciepła na początku spalania. Wyraźniejsze zmiany występują dla większego wykładnika funkcji Wibego. Warto również zwrócić uwagę, że charakterystyczny punkt przegięcia na linii ciśnienia odpowiadający spalaniu drugiej dawki ON zanika wraz ze zwiększaniem kąta spalania. Wynika to $\mathrm{z}$ $\mathrm{m}_{\mathrm{on1}}=\mathrm{m}_{\mathrm{on} 2}=1,0 ; \quad \mathrm{m}_{\mathrm{wg}}=1,8$

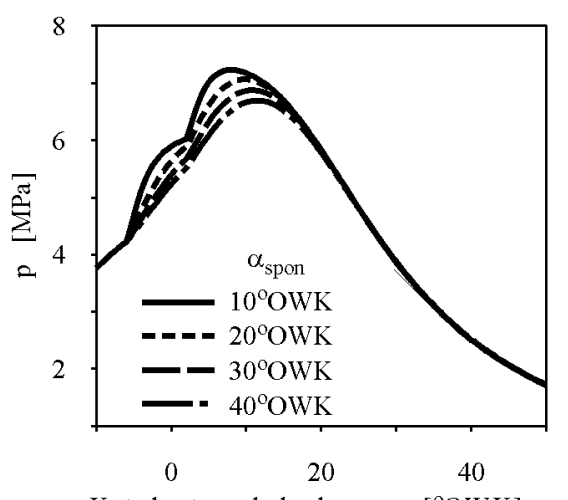

Kąt obrotu wału korbowego [ ${ }^{\circ} \mathrm{OWK}$ ]
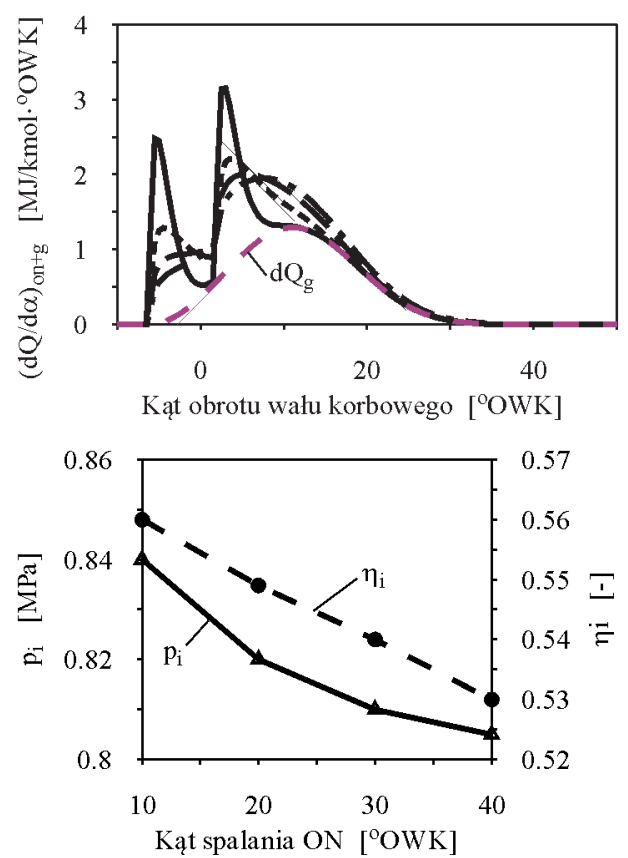

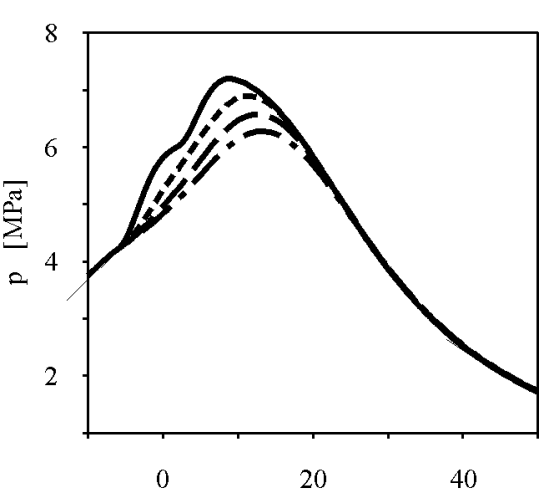

Kąt obrotu wału korbowego [ $\left.{ }^{\circ} \mathrm{OWK}\right]$
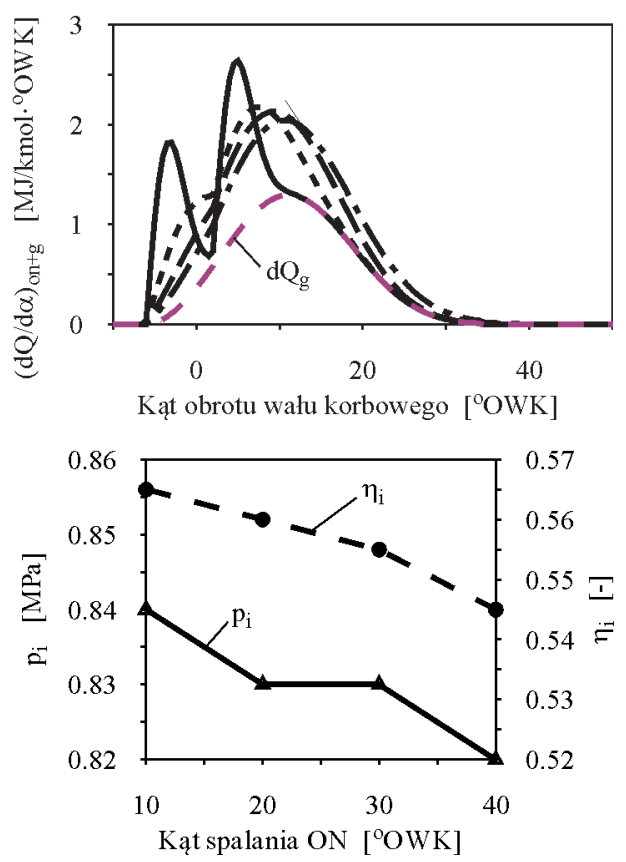

Fig. 6. The influence of the diesel oil combustion angle on selected engine parameters: $\alpha_{\mathrm{sp1}}=\alpha_{\mathrm{sp} 2} ; \alpha_{\mathrm{spg}}=$ const; $\mathrm{m}_{\mathrm{wg}}=$ const; engine speed $1400 \mathrm{rpm}$; maximum load

Rys. 6. Wptyw kąta spalania oleju napędowego na wybrane parametry silnika: $\alpha_{s p 1}=\alpha_{s p 2} ; \alpha_{s p g}=$ const; $m_{w g}=$ const; prędkość obrotowa $1400 \mathrm{obr} / \mathrm{min}$; obciązenie maksymalne nakładania się wzajemnego spalania obydwu dawek, co wyraźnie widoczne jest na krzywych szybkości wydzielania ciepła ze spalania ON $(\mathrm{dQ} / \mathrm{d} \alpha)_{\text {on }}$, szczególnie dla większego wykładnika funkcji Wibego.

Zmiany kąta spalania ON bardzo wyraźnie wpływają na całkowitą szybkość wydzielania ciepła $(\mathrm{dQ} / \mathrm{d} \alpha)$ ${ }_{\text {on }+\mathrm{g}}$. Na rysunkach przedstawiających krzywe $(\mathrm{dQ} / \mathrm{d} \alpha)$ ${ }_{\text {on }+\mathrm{g}}$ dodatkowo naniesiono linią przerywaną szybkość wydzielania ciepła ze spalania gazu, która jest składnikiem sumy tworzącej wartość $(\mathrm{dQ} / \mathrm{d} \alpha)_{\text {on+g }}$. Maksymalne wartości $(\mathrm{dQ} / \mathrm{d} \alpha)_{\text {on+g }}$ maleją w miarę wzrostu kąta spalania ON i występują coraz później.

Wzrost kąta spalania ON niekorzystnie wpływa na średnie ciśnienie indykowane i sprawność indykowaną. Obydwie wartości maleją monotonicznie wraz ze zwiększaniem kąta spalania $\mathrm{ON}$.

Jeszcze bardziej na przebieg ciśnienia wpływa zmiana kąta spalania gazu (rys. 7a). Jest to zrozumiałe, bowiem paliwo gazowe stanowi podstawową porcję energii dostarczanej do silnika i zmiany dynamiki jej spalania muszą wpływać na parametry 
identical for both fuel doses and for an average dynamics of $\mathrm{CNG}$ combustion of $\mathrm{m}_{\mathrm{wg}}=1.8$. The angle of CNG combustion was constant irrespective of the angle of combustion of diesel oil. It s noteworthy that in real engine operation the changes of the combustion angle of liquid fuels influence the combustion angle of $\mathrm{CNG}$ but it is the mixture composition (CNG-air) that is of importance particularly in the range of lean compositions.

As the angle of diesel fuel doses increases the maximum pressures decrease and the point of their occurrence is shifted to the right towards greater angles after TDC. This results from a gradual decrease in the heat release in the beginning of the combustion. More conspicuous changes are visible for greater exponents of the Wiebe function. It is also noteworthy that the characteristic inflection on the pressure line corresponding to combustion of the additional diesel fuel dose fades as the combustion angle increases. This results from the overlapping of the combustion of both fuel doses, which is clearly seen in the curves of heat release rate during combustion of diesel oil $(\mathrm{dQ} / \mathrm{d} \alpha)_{\text {on }}$, particularly for greater Wiebe function exponents.

The changes in the combustion angle of diesel oil vary clearly influence the total heat release rate $(\mathrm{dQ} / \mathrm{d} \alpha)_{\text {on }+\mathrm{g}}$. In the figures showing the curves $(\mathrm{dQ} / \mathrm{d} \alpha)_{\text {on }+\mathrm{g}}$ an additional dotted line was overlain denoting the heat release rate from the combustion of $\mathrm{CNG}$ being the component of the sum constituting the value $(\mathrm{dQ} /$ $\mathrm{d} \alpha)_{\text {on }+\mathrm{g}}$. The maximum values of $(\mathrm{dQ} / \mathrm{d} \alpha)_{\text {on }+\mathrm{g}}$ decrease as the combustion angle of diesel oil increases and their occurrence is delayed.

An increase in the combustion angle of diesel oil has an adverse effect on the average indicated pressure and indicated efficiency. Both values decrease monotonically as the combustion angle of diesel oil increases.

The change of the combustion angle of termodynamiczne czynnika w komorze spalania. Ciśnienie maksymalne maleje wraz ze zwiększaniem kąta spalania gazu, a dynamika wydzielania ciepła na początku spalania maleje, co skutkuje przesunięciem linii ciśnienia w prawo w kierunku późniejszych kątów po GMP. Zmiany dynamiki spalania gazu wyraźnie widoczne są na liniach szybkości wydzielania ciepła $(\mathrm{dQ} / \mathrm{d} \alpha)_{\mathrm{g}}$, gdzie widać zmniejszające się wartości maksymalne $(\mathrm{dQ} / \mathrm{d} \alpha)_{\mathrm{g}}$ oraz opóźnienie punktu ich występowania wraz ze zwiększaniem kąta spalania gazu (rys. 7c).

Efektem omawianych zmian jest monotoniczne zmniejszanie średniego ciśnienia indykowanego i sprawności indykowanej silnika wraz ze wzrostem kąta spalania gazu (rys. 7e). Potwierdza to znane z badań fakty, że wysokie sprawności ogólne silników dwupaliwowych uzyskiwane są w zakresach bogatych mieszanin paliwowo-powietrznych o największej szybkości płomienia i relatywnie krótkich

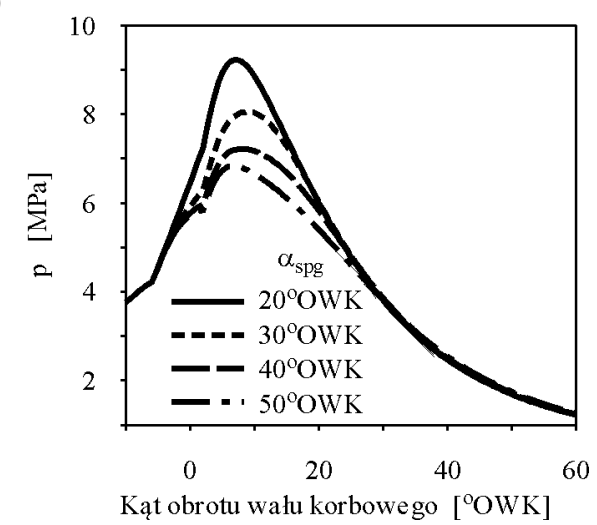

c)

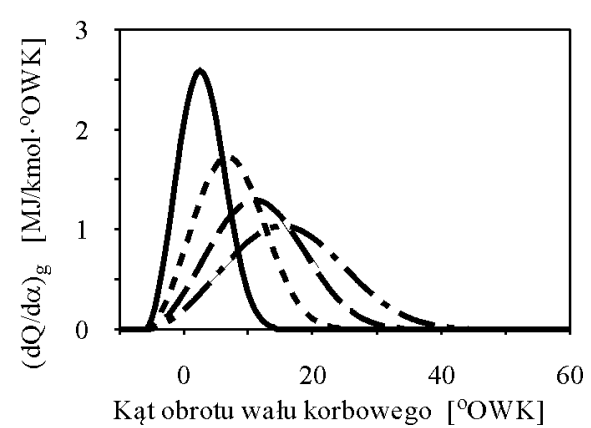

e) 0.88

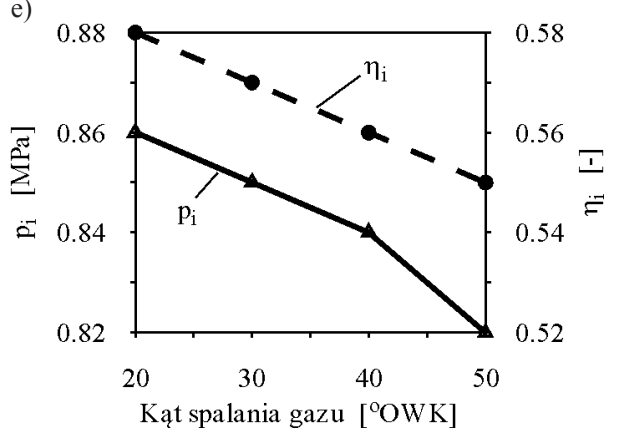

b)
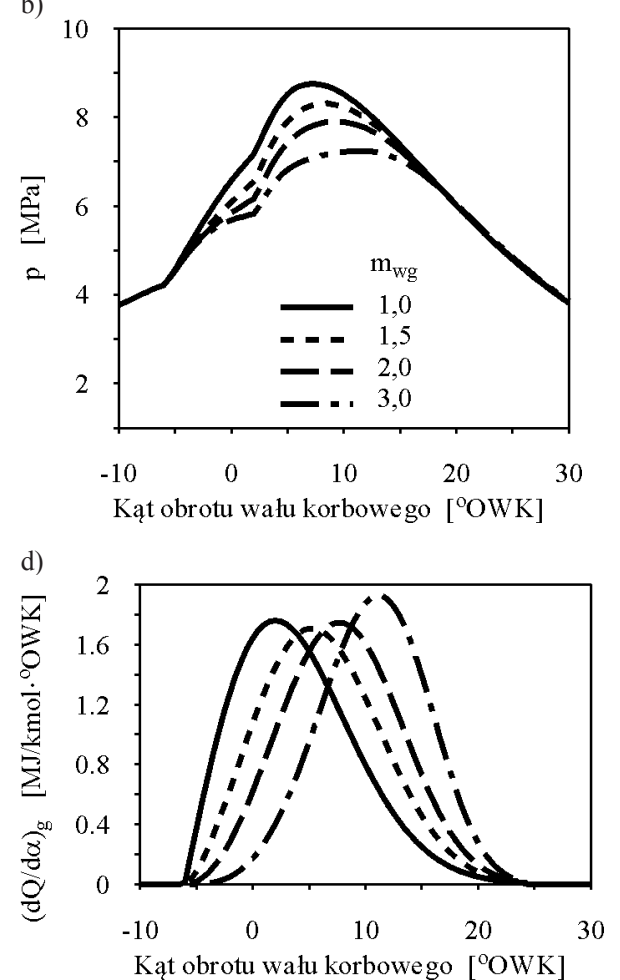

f)

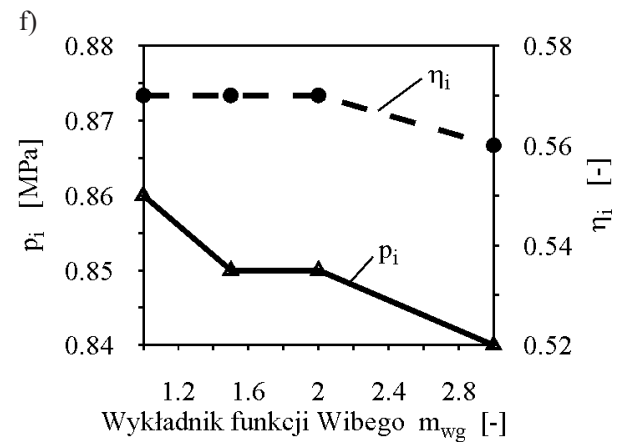

Fig. 7. The influence of the CNG combustion angle and Wiebe function exponent $\mathrm{m}_{\mathrm{wg}}$ on selected engine parameters: $\alpha_{\mathrm{sp} 1}=\alpha_{\mathrm{sp} 2}=$ const; $\mathrm{m}_{\mathrm{on} 1}=\mathrm{m}_{\mathrm{on} 2}=$ const; engine speed $1400 \mathrm{rpm} ;$ maximum load

Rys. 7. Wptyw kąta spalania gazu i wyktadnika funkcji Wibego mwg na wybrane parametry silnika: $\alpha_{s p 1}=\alpha_{s p 2}=$ = const; $m_{\text {on } 1}=m_{\text {on } 2}=$ const; prędkość obrotowa $1400 \mathrm{obr} / \mathrm{min} ;$ obciązenie maksymalne 
CNG influences the course of the pressure even more (Fig. $7 \mathrm{a})$. It is obvious as the gas fuel constitutes the basic portion of energy supplied to the engine and changes in the dynamics of its combustion must have impact on the thermodynamic parameters of the medium inside the cylinder. The maximum pressure drops as the CNG combustion angle increases and the dynamics of the heat release decreases in the beginning of the combustion, which results in shifting of the pressure line to the right towards more delayed angles after TDC. The changes in the dynamics of CNG combustion are clearly visible on the lines of heat release rates $(\mathrm{dQ} / \mathrm{d} \alpha)_{\mathrm{g}}$ where we can see the decreasing maximum values $(\mathrm{dQ} / \mathrm{d} \alpha)_{\mathrm{g}}$ and a delay of the point of their occurrence as the angle of the CNG combustion increases (Fig. 7c).

The effect of the discussed changes is the monotonic decrease of the mean indicated pressure and indicated efficiency of the engine as the $\mathrm{CNG}$ combustion angle increases (Fig. 7e). This confirms the fact known from research that high overall efficiency of dual fuel engines is obtained in the range of rich air-fuel mixtures of the highest flame velocity and relatively short combustion times. Such conditions can be obtained for engine operating at maximum loads and small pilot fuel doses. The simulation analysis explains why the majority of applications of dual fuel engines were stationary (power generators).

Figures $7 \mathrm{~b}, 7 \mathrm{~d}, 7 \mathrm{f}$ show a simulation of the change in the dynamics of the $\mathrm{CNG}$ combustion at a constant combustion angle. The Wiebe function coefficient $\mathrm{m}_{\mathrm{wg}}$ varied in the range from $1.0 \div 3.0$. The change in exponent $\mathrm{m}_{\mathrm{wg}}$ results in a delay of the maximum dynamics of heat release, which triggers changes in the course of the pressure of the medium during the combustion. The maximum pressures decrease as the exponent $\mathrm{m}_{\mathrm{wg}}$ grows and the point of their occurrence is delayed. The shape of the pressure curves is clearly modified as exponent $\mathrm{m}_{\mathrm{wg}}$, changes, particularly in the beginning of combustion (under simulated conditions great combustion dynamics starts after TDC).

The change in the CNG combustion dynamics within the range of the change of exponent $\mathrm{m}_{\mathrm{wg}}=1.0 \div 2.0$ does not influence the indicated engine efficiency. Only a significant delay of the greatest combustion dynamics, occurring for exponent $\mathrm{m}_{\mathrm{wg}}=3.0$ results in a reduction of the indicated efficiency. This may imply that in real engine processes there exists a certain range of CNG-air mixture composition in which the changes in the indicated efficiency will be miniscule. Only the leaning of the mixture outside of this range may result in a decrease in the engine efficiency.

The change of the CNG combustion dynamics reducing the pressure in the high-pressure part of combustion in a dual fuel engine results in a reduction of the mean indicated pressure. This will lead to decreased engine performance. In a supercharged engine this is not a problem as a reduction of the torque resulting from a lean mixture can be compensated by an increase in the supercharging rate. Such actions can be realized to reduce the emission of $\mathrm{NO}_{\mathrm{x}}$ without deteriorating the efficiency and performance of a dual fuel engine. czasach spalania. Warunki takie można uzyskać w silnikach pracujących przy maksymalnym obciążeniu i przy małych dawkach inicjujących. Analiza symulacyjna wyjaśnia dlaczego większość zastosowań praktycznych silników dwupaliwowych dotyczyła silników stacyjnych (przeważnie generatorowych).

$\mathrm{Na}$ rysunkach 7b, 7d, 7f przedstawiono symulację zmiany dynamiki spalania gazu przy stałym kącie spalania. Współczynnik funkcji Wibego $\mathrm{m}_{\mathrm{wg}}$ był zmieniany w zakresie $1,0 \div 3,0$. Zmiana wykładnika $\mathrm{m}_{\mathrm{wg}}$ powoduje opóźnianie maksymalnej dynamiki wydzielania ciepła, co sprawia zmiany w przebiegu ciśnienia czynnika podczas spalania. Maksymalne ciśnienia maleją w miarę zwiększania wykładnika $m_{w g}$, a punkt ich występowania ulega opóźnieniu. Kształt krzywych ciśnienia ulega wyraźnym zmianom wraz ze zmianami wykładnika $\mathrm{m}_{\mathrm{wg}}$, zwłaszcza na początku spalania (w symulowanych warunkach duża dynamika spalania rozpoczyna się po GMP).

Zmiana dynamiki spalania gazu w zakresie zmian wykładnika $\mathrm{m}_{\mathrm{wg}}=1,0 \div 2,0$ nie wpływa na sprawność indykowaną silnika. Dopiero znaczne opóźnienie największej dynamiki spalania, występujące dla wykładnika $\mathrm{m}_{\mathrm{wg}}=3,0$, powoduje zmniejszenie sprawności indykowanej. Może to sugerować, że w rzeczywistych procesach silnikowych istnieje pewien przedział składów mieszaniny gaz-powietrze, w których zmiany sprawności indykowanej będą niewielkie. Dopiero zubożenie mieszaniny poza zakresem tego przedziału może powodować zmniejszenie sprawności silnika.

Zmiana dynamiki spalania gazu zmniejszająca ciśnienia w wysokociśnieniowej części procesu spalania silnika dwupaliwowego powoduje zmniejszanie średniego ciśnienia indykowanego. Będzie to prowadziło w praktyce do zmniejszenia osiągów silnika. W silniku doładowanym nie stanowi to istotnego problemu, bowiem zmniejszenie momentu obrotowego powodowane zubożeniem mieszaniny palnej może być kompensowane wzrostem stopnia doładowania. Działania takie mogą być przykładowo realizowane w celu zmniejszenia emisji $\mathrm{NO}_{\mathrm{x}}$ bez straty osiągów i sprawności silnika dwupaliwowego.

\section{Wnioski}

W artykule przedstawiono jedynie część badań symulacyjnych i obliczeń z wykorzystaniem opracowanego modelu teoretycznego, jakie wykonano przy okazji realizacji niniejszej pracy. Uzyskane wyniki i doświadczenia zdobyte przy wszystkich symulacjach pozwalają na sformułowanie następujących wniosków:

- Opracowany model teoretyczny z wystarczającą, z technicznego punktu widzenia, dokładnością odwzorowuje rzeczywiste przebiegi procesów zachodzących w dwupaliwowych silnikach ZS z dzieloną dawką inicjującą.

- Przyjęte w modelu zmienne niezależne umożliwiają symulowanie przebiegu wydzielania ciepła, indywidualne dla dwóch dawek ON i gazu. Model wykazuje dużą czułość na zmiany parametrów niezależnych, co umożliwia symulację zróżnicowanych procesów rzeczywistych. 


\section{Conclusions}

The paper presents only a part of the simulation research and calculations made with the developed theoretical model. The obtained results and experience gained during the said simulations lead to a formulation of the following conclusions:

- The developed theoretical model with a sufficient accuracy reflects the actual processes in dual fuel diesel engines with a divided pilot injection.

- The independent variables adopted in the model enable simulating the course of heat release, individual for the two fuel doses of diesel oil and CNG. The model is highly sensitive to changes of the independent parameters, which enables a simulation of varied actual processes.

- The model is universal, yet the simulation for individual engines requires its validation based on simplified engine tests. This allows determining of the approximate range of changes of such parameters as: self-ignition delay angle, Wiebe function exponents for the fuels and their doses and combustion angles. The changes of the said parameters are individual for each engine and are related to its fuel system, geometry of the combustion chamber and heat transfer systems. The validation allows an approximation of the simulation results to the given requirements of individual engines much different from the engine discussed in this paper.

- The application of moderate injection delay angles of the additional fuel dose in the range $5 \div 15^{\circ} \mathrm{CA}$ slightly influences the combustion parameters: maximum pressure of the medium during the combustion, indicated efficiency and mean indicated pressure. Only wider angles of $>15$ ${ }^{\circ} \mathrm{CA}$ result in a decrease of the indicated efficiency by more than $3 \%$. The maximum heat release rate decreases as the delay angle increases, which may lead to a reduction in the $\mathrm{NO}_{\mathrm{x}}$ and noise emission.

- The changes in the diesel oil combustion dynamics realized through changes of the Wiebe function exponents $\mathrm{m}_{\mathrm{on}}$ and $m_{\text {on } 2}$ slightly influence the pressure course, indicated efficiency and mean indicated pressure, which results from small energy shares of the fuel doses in the total energy supplied to the engine.

- A significant impact on the pressure course have the diesel fuel combustion angles depending on the quality of fuel atomization and thermodynamic parameters of the medium in the beginning of combustion. An increase in the combustion angles $\alpha_{\mathrm{sp} 1}, \alpha_{\mathrm{sp} 2}$ results in a decrease in the maximum pressure of the medium, heat release rate $(\mathrm{dQ} / \mathrm{d} \alpha)_{\max }$, indicated efficiency and mean indicated pressure.

- A change in the dynamics of CNG combustion, depending mostly on its composition, significantly influences the combustion parameters. An increase in the combustion angle results in a monotonic decrease of both efficiency $\eta_{i}$, and pressure $p_{i}$, which should have an adverse effect on the external engine parameters. A change in the $\mathrm{CNG}$ combustion angle results in a decrease of the maximum dynamics of heat release from the gas and that results in a reduction of the maximum value of $(\mathrm{dQ} / \mathrm{d} \alpha)_{{ }_{\mathrm{on}+\mathrm{g}}}$.
- Model ma charakter uniwersalny, jednak symulacja dla konkretnego silnika wymaga walidacji modelu na podstawie uproszczonych badań silnikowych. Pozwala to na określenie przybliżonych zakresów zmian, takich parametrów jak: kąt opóźnienia samozapłonu, wykładniki funkcji Wibego dla dawek i paliw, kątów spalania. Zmiany wymienionych parametrów są indywidualne dla konkretnego silnika i związane z jego systemem zasilania, wymiarami geometrycznymi komory spalania oraz systemem odprowadzania ciepła. Walidacja pozwala przybliżyć wyniki symulacji do określonych potrzeb konkretnego silnika znacznie różniącego się od silnika stosowanego w tej pracy.

- Stosowanie umiarkowanych kątów opóźnienia wtrysku dawki dodatkowej w zakresie $5 \div 15^{\circ} \mathrm{OWK}$ nieznacznie wpływa na parametry spalania takie jak: ciśnienie maksymalne czynnika w czasie spalania, sprawność indykowana i średnie ciśnienie indykowane. Dopiero większe kąty opóźnienie $>15{ }^{\circ} \mathrm{OWK}$ powodują zmniejszenie sprawności indykowanej o ponad 3\%. Maksymalna szybkość wydzielania ciepła maleje wraz ze zwiększaniem kąta opóźnienia, co może wpływać na zmniejszenie emisji $\mathrm{NO}_{x}$ i hałaśliwości pracy silnika.

- Zmiany dynamiki spalania oleju napędowego realizowane

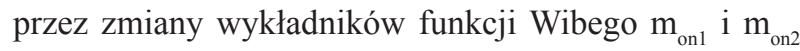
nieznacznie wpływają na przebieg ciśnienia, sprawność indykowaną oraz średnie ciśnienie indykowane, co wynika z małych udziałów energetycznych dawek w całkowitej ilości energii dostarczanej do silnika.

- Istotny wpływ na przebieg ciśnienia czynnika mają kąty spalania ON zależne do jakości rozpylenia paliwa i parametrów termodynamicznych czynnika na początku spalania. Wzrost kątów spalania $\alpha_{\mathrm{sp1}}, \alpha_{\mathrm{sp} 2}$ powoduje zmniejszanie ciśnienia maksymalnego czynnika, szybkości wydzielania ciepła $(\mathrm{dQ} / \mathrm{d} \alpha)_{\max }$, sprawności indykowanej i średniego ciśnienia indykowanego.

- Zmiana dynamiki spalania gazu zależna głównie od jego składu wpływa istotnie na parametry spalania. Wzrost kąta spalania gazu powoduje monotoniczne zmniejszanie zarówno sprawności $\eta_{i}$, jak i ciśnienia pi, co powinno niekorzystnie wpłynąć na parametry zewnętrzne silnika. Zmiana kąta spalania gazu powoduje zmniejszanie maksymalnej dynamiki wydzielania ciepła z gazu, a to powoduje zmniejszanie maksymalnej wartości $(\mathrm{dQ} / \mathrm{d} \alpha)_{{ }_{\text {on }}+\mathrm{g}}$.

- Zmiana dynamiki spalania gazu przy stałym kącie spalania osiągana przez zmianę wykładnika $\mathrm{m}_{\mathrm{wg}}$ w niewielkim stopniu wpływa na maksymalne wartości szybkości wydzielania ciepła $\mathrm{z}$ gazu $(\mathrm{dQ} / \mathrm{d} \alpha)_{\mathrm{g}}$. Powoduje jednak opóźnienie punktu jej występowania, co wpływa na zmiany ciśnienia w wysokociśnieniowych zakresach procesu spalania. Skala tych zmian jest jednak mniejsza niż przy zmianie kąta spalania gazu. Zmiana dynamiki dla zakresu $\mathrm{m}_{\mathrm{wg}}=1,0 \div 2,0$ prawie nie wpływa na sprawność indykowaną silnika, a to pozytywnie rokuje na możliwości doboru regulacji składu mieszaniny gazowej w rzeczywistych procesach silnikowych. 
- A change in the dynamics of CNG combustion at a constant combustion angle obtained through changing of exponent $\mathrm{m}_{\mathrm{wg}}$ slightly influences the maximum values of the heat release rate from the gas $(\mathrm{dQ} / \mathrm{d} \alpha)_{\mathrm{g}}$. It leads to a delay of the point of its occurrence, which has impact on the pressure changes in the high-pressure part of the combustion. The scale of these changes is smaller than in the case of $\mathrm{CNG}$ combustion angle. A change in the dynamics for range $\mathrm{m}_{\mathrm{wg}}=1.0 \div 2.0$ has almost no influence on the engine indicated efficiency and this is promising in terms of the possibilities of controlling of the gas mixture composition in actual engine processes.

- The application of simulation research allows a varied evaluation of the combustion parameters and engine performance and facilitates reasoning when selecting the engine parameters. This should significantly reduce the costly engine tests.

- The comparisons of the simulated pressure courses with the measured pressures indicate that the tested model should undergo an improvement, particularly in heat transfer to the walls. This will ensure a better convergence of the calculation results with the actual engine processes.
- Zastosowanie badań symulacyjnych pozwala na różnorodne oceny parametrów spalania, osiągów silnika i ułatwia wnioskowanie przy doborze parametrów regulacyjnych silnika. Powinno to ograniczyć w znacznym stopniu kosztowne badania silnikowe.

- Porównania symulowanych przebiegów ciśnień z ciśnieniami zmierzonymi wskazują, że badany model powinien być doskonalony, głównie w zakresie wymiany ciepła ze ściankami. Pozwoli to na lepsze dopasowanie wyników obliczeń do rzeczywistych procesów silnikowych.

Paper reviewed/Artykut recenzowany

\section{Bibliography/Literatura}

[1] Abd Alla G.H., Soliman H.A., Badr O.A., Abd Rabbo M.F.: Combustion quasi-two zone predictive model for dual fuel engines. Energy Conversion and Management 42 (2001) 1477-1498, 2001.

[2] Cailool Chr., Delorme T., Denis P., Berardi G., Porterie B.: A Combustion Model for Analyzing the Effects of Natural Gas Composition on the Operation of a Spark Ignition Engine. SAE Paper No. 2002-01-2236, 2002.

[3] Hountalas D.T., Papagiannakis R.G.: A Simulation Model for the Combustion Process of Natural Gas Engines with Pilot Diesel Fuel as an Ignition Source. SAE Paper 2001-01-1245.

[4] Singh S., Liang L., Kong S.C., Reitz R.D.: Development of a Flame Propagation Model for Dual-Fuel Partially Premixed Compression Ignition Engines. International Journal of Engine Research, vol. 7 no. 1, 65-75, 2006.

[5] Matyjasik M.: Aktywizacja procesu spalania mieszaniny gazpowietrze w silnikach dwupaliwowych przez podział dawki inicjującej oleju napędowego. Rozprawa doktorska, ATH, Bielsko-Biała 2012.

[6] Stelmasiak Z.: The Modeling of the Gas Combustion Course Using Theoretical Diphase Model that Describes the Combustion in a Dual Fuel Engine Fed with Both Natural Gas and
Diesel Oil. Fisita 2002 World Automotive Congress, Paper No. F02 V211.

[7] Stelmasiak Z.: Modelowanie przebiegu spalania w dwupaliwowym silniku o zapłonie samoczynnym zasilanym gazem. Polska Akademia Nauk Oddział w Krakowie, Teka Komisji Naukowo-Problemowej Motoryzacji nr ISDN 1642-1639, s. 447-456, Kraków 2003. Konferencja n.t. Badania symulacyjne w technice samochodowej, Kazimierz Dolny 26-28 maja 2003.

[8] Stelmasiak Z., Larisch J., Gilowski T., Matyjasik M.: The optimization of combustion process in a dual fuel engine with Common Rail and gas injection systems, International Congress on Combustion Engines PTNSS KONGRES-2007 „The Development of Combustion Engines”, Kraków 2023.05.2007, Paper No. P07-C004.

[9] Stelmasiak Z.: The Combustion Controlling in the Dual Fuel CI Engine by Pilot Dose Division, Combustion Engines No. $3 / 2011$.

[10] Stelmasiak Z.: Possibility of Improvement of Some Parameters of Dual Fuel CI Engine by Pilot Dose Division, Journal of Polish Cimac, Vol. 6, No.1/2011, pp. 181-189, 2011.
Zdzisław Stelmasiak, DSc., DEng. - Professor in the Faculty of Mechanical Engineering at University of Bielsko-Biala.

Dr hab. inż. Zdzisław Stelmasiak, prof. ATH-profesor na. Wydziale Budowy Maszyn i Informatyki Akademii Techniczno-Humanistycznej w BielskuBiatej.

e-mail: zstelmasiak@ath.bielsko.pl

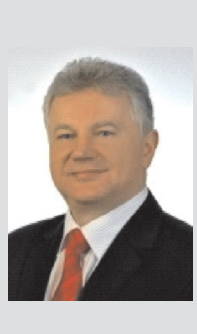

Marcin Matyjasik, MEng. - doctoral student at the Faculty of Machine Design and Information Technology, University of Bielsko-Biała.

Mgr inż. Marcin Matyjasik-doktorant na Wydziale Budowy Maszyn i Informatyki, Akademii Techniczno-Humanistycznej w Bielsku-Białej. 